$A L .2 .2007-204$
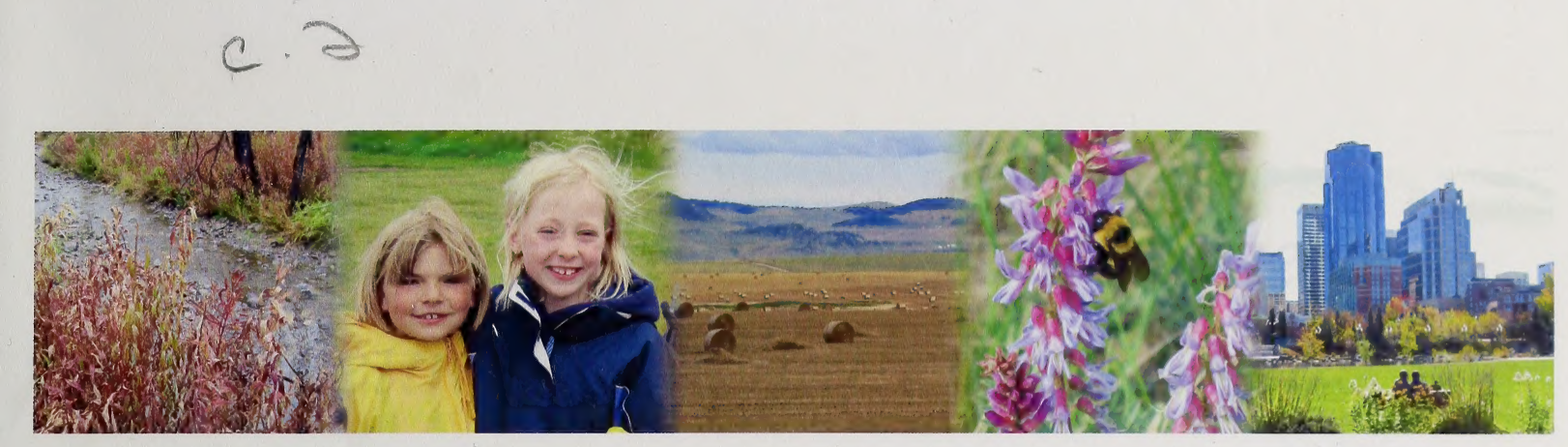

Southern Alberta Landscapes MEETING the Challenges AHEAD

\title{
Invasion of Non-Native Plant Species \\ Report of Workshop Results
}

\author{
Prepared for \\ Alberta Environment \\ By Cheryl Bradley \\ Lethbridge $\mathrm{AB}$ \\ April 2003
}


Digitized by the Internet Archive in 2016 


\title{
Southern Alberta Landscapes: Meeting the Challenges Ahead
}

\section{Invasion of Non-Native Plant Species}

\section{Report of Workshop Results}

\author{
Prepared for \\ Alberta Environment \\ By Cheryl Bradley \\ Lethbridge $A B$ \\ April 2003
}

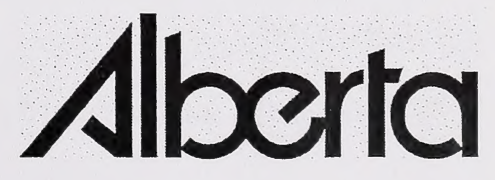




\section{Southern Alberta Landscapes: \\ Meeting the Challenges Ahead}

\section{Invasion of Non-Native \\ Plant Species}

Report of Workshop Results 
ISBN: 978-0-7785-6742-4 (Print version)

ISBN: 978-0-7785-6743-1 (Online version)

Website: www.gov.ab.ca/env/

Disclaimer: The contents of this document have been prepared with funds from Alberta Environment but do not necessarily reflect the Ministry's views or policies. Any mention of trade names or commercial products does not constitute an endorsement or recommendation for use.

Any comments, questions or suggestions on the content of this document may be directed to:

Regional Environmental Management

Alberta Environment

3rd Floor, Deerfoot Square

2938 - 11 Street N. E.

Calgary, Alberta T2E 7L7

$\mathrm{Ph}:$ (403) 297-7602

Fx: (403) 297-6069

Additional print copies of this document are available from:

Information Centre

Alberta Environment

Main Floor, Oxbridge Place

9820-106 Street

Edmonton, Alberta T5K 2J6

$\mathrm{Ph}:(780)$ 427-2700

Fx: (780) 422-4086

Outside of Edmonton dial 310-0000 for toll-free connection

Email: env.infocent@gov.ab.ca

Copyright in this publication, regardless of format, belongs to Her Majesty the Queen in right of the Province of Alberta. Reproduction of this publication, in whole or in part, regardless of purpose, requires the prior written permission of Alberta Environment.

(C) Her Majesty the Queen in right of the Province of Alberta, 2007. 


\section{CONTENTS}

1.0 BACKGROUND

2.0 WORKSHOP OBJECTIVES AND PARTICIPANTS

3.0 INFORMATION SOURCES

3.1 Occurrence of Non-native Species in Native Vegetation

3.2 Rates of Invasion of Non-native Species

3.3 Restoration Potential

4.0 MODELING CONSIDERATIONS

4.1 Invasive Non-Native Species Groups

4.2 Invasion Rate vs. Invasion Corridor

4.3 Land Use Footprint Groups

4.4 Reclamation Considerations

5.0 Estimated Invasion Rates

5.1 Assumptions

\section{List of Appendices}

APPENDIX A - WORKSHOP AGENDA

APPENDIX B - PARTICIPANTS LIST

APPENDIX C - LIST OF REFERENCES

\section{$\underline{\text { List of Tables }}$}

Table 1: Percent frequency ${ }^{1}$ of invasive agronomic grasses in range plots by natural subregion and within riparian plots in southern Alberta.

Table 2. Percent frequency ${ }^{1}$ of noxious and nuisance weeds within range plots by natural subregion and within riparian plots in southern Alberta.

Table 3: Estimated Rates of Invasion of Agronomic Plant Species for each Native Vegetation Cover Class and Linear Land Use Footprint Type Identified in ALCES 
The Southern Alberta Landscapes: Meeting the Challenges Ahead, coordinated by Alberta Environment, will look at social, economic, and environmental information for southern Alberta to take stock of our current situation and to assess the consequences of potential changes over the next two generations. Its purpose will be to identify the issues that need to be addressed to ensure a sustainable future, that is, how can we meet our social and economic needs whilst ensuring reasonable environmental quality?

The SAL study area comprises all of the Grasslands Natural Region, the South Saskatchewan River Basin and the Cypress Hills. This includes about $17 \%$ of the province and about $60 \%$ of Alberta's population.

Phase I of SAL will appraise the current state of the region, identify a vision, goals, and principles for sustainable development, make policy recommendations and identify the key issues that need to be addressed and in what order of priority. In determining the current state of the region, the Strategy Development Group is compiling air, water, land use and socio-economic data, building landscape modeling and simulation tools and gathering information about important resource sectors. The model being used to integrate the data and predict the cumulative effects of various growth scenarios is ALCES, developed by Brad Stelfox.

A significant gap in data and predictive capability for ALCES, identified by the Strategy Development Group, is change or loss of native vegetation due to invasion of non-native species from disturbances. To address this gap, Cheryl Bradley was contracted by Alberta Environment, Southern Region to organize a workshop of individuals with expertise in non-native plant species invasion into native vegetation and to prepare a report of workshop results. The workshop was held in Lethbridge on Monday, April 14, 2003.

\subsection{WORKSHOP OBJECTIVES AND PARTICIPANTS}

The purpose of the workshop was to determine how ALCES should model effects of non-native plant species invasion from a variety of land use footprints into native vegetation in southern Alberta. Specific objectives were fourfold.

- Review current information on invasion of non-native plants into native vegetation types defined in ALCES.

- Define one or more groups of invasive non-native plant species which should be modeled in ALCES.

- Identify land use footprints defined in ALCES that create opportunities for invasion of non-native plants into native vegetation types.

- For each invasive species group, define how ALCES should model invasion from each land use footprint into each native vegetation type.

The agenda for the workshop is included in Appendix A.

Seven individuals with expertise in non-native plant species invasion into native vegetation participated in the workshop. One individual, Lorna Allen, was not able to attend but provided background information and suggestions prior to the workshop. Affiliation and relevant experience of participants is as follows.

\section{Barry Adams}

Public Lands, Alberta Sustainable Resource Development, Lethbridge

Barry has worked as a range specialist in southern Alberta for 27 years. Through his extensive work in range survey, rangeland health assessment, and range reclamation, he has acquired considerable data and knowledge regarding the characteristics and management of non-native plant species invasion into native range throughout the Grassland Natural Region. 


\section{Mike Alexander}

Public Lands, Alberta Sustainable Resource Development, Blairmore

Mike has worked several years as a range management specialist in southwestern Alberta, primarily in the Montane, Subalpine and Foothills Natural Regions. He has monitored range reference plots established in the 1950s and has sound knowledge of changes in vegetation inside and outside of these plots over several decades. He also has a good understanding of responses of native range to disturbances from industrial development.

\section{Lorna Allen}

Alberta Natural Heritage Information Centre, Community Development, Edmonton

Lorna is a vegetation ecologist who has worked several years compiling and analyzing data on vegetation types throughout Alberta. She conducts vegetation inventories in protected areas and coordinates a program to develop a tracking list of vegetation associations considered of special conservation concern, to undertake an annual review of the tracking list, and to address gaps in our knowledge of vegetation associations which may be at risk.

\section{Cheryl Bradley}

Environmental Consultant, Lethbridge

Cheryl is a private consultant who has worked over two decades in Alberta on vegetation and rare plant species inventory, vegetation mapping, environmental assessment and facilitation of public process to develop environmental policy.

\section{Lorne Cole}

Special Areas Board, Alberta Municipal Affairs, Hanna

Lorne is a range specialist responsible for managing grazing and industrial activity on three million acres of range under the jurisdiction of the Special Areas Board in east central Alberta. Some of the range is native and some recovering from abandoned cultivation in the early 1900 s. He also is involved in municipal efforts to control invasive non-native species.

\section{Darcy Henderson}

PhD Student, University of Alberta, Edmonton

Darcy is working with Dr. Anne Naeth on researching the ecology of Crested Wheat Grass. He is three years into his doctoral program. Prior to coming to the University of Alberta, Darcy worked with the Meewasin Conservation Authority near Saskatoon, on control of invasive plant species.

\section{Arin MacFarlane}

MSc Student, University of Alberta, Edmonton

Arin's current research with Dr. Stan Boutin focuses on seismic lines and their impact on aspen forest structure and composition as well as on spread of non-native plant species into native vegetation in the Alberta-Pacific Forest Industries Inc. Forest Management Area in north central Alberta. Prior to this Arin completed a BSc honors thesis and industrial internship examining tree regeneration on seismic lines in the Boreal Forest Natural Region.

\section{Marilyn Neville}

Consultant, Gramineae Consultants, Lundbreck

Marilyn is a reclamation specialist who has been working since the mid-1980s on reclaiming disturbances from construction of energy projects. She has extensive experience in the Grassland, Parkland and Foothills Natural Regions planning energy developments to minimize disturbance and reclaiming large pipeline right-of-ways.

Contact information for participants in provided in Appendix B. 


\section{0}

Prior to the workshop participants were asked to identify published information sources, in journals and reports by government and consultants, which they would rely on in making their assessments regarding invasion on non-native plants into native vegetation. A list of these references is provided in Appendix C.

Participants collectively have considerable experience and unpublished data regarding native plant communities and invasion by non-native plant species in Alberta. Key observations made by participants are recorded under three categories.

- Occurrence of non-native species in native vegetation

- Rates of invasion of non-native species

- Restoration potential

\subsection{Occurrence of Non-native Species in Native Vegetation}

- Results of a study on species composition of upland grassland sites in the Central Parkland Natural Subregion were provided by Lorna Allen. Of 1,686 sites surveyed, 582 (34.5\%) were dominantly nonnative communities. Plains rough fescue occurred at $549(32.7 \%)$ sites and of these only $211(12.5 \%)$ had plains rough fescue communities (Holcroft-Weerstra, 2003). Invasive non-native plants were found in $41.8 \%$ of the plains rough fescue communities. Invaders were predominantly awnless brome and Kentucky bluegrass and most frequently occurred in rough fescue grasslands assessed as in poor condition. The data suggests there is widespread invasion of agronomic grasses into plains rough fescue grasslands in central Alberta and conversion to grasslands dominated by non-native species has and is occurring.

- Analysis of the frequency of four agronomic grasses and five noxious and nuisance weeds within several hundred range plots within the Dry Mixedgrass, Mixedgrass, Foothills Fescue and Foothills Parkland Natural Subregions as well as within riparian plots throughout southern Alberta was provided by Barry Adams (Tables 1 and 2). Analysis shows that grasslands of the Foothills Fescue and Foothills Parkland Natural Subregions, which are underlain by black soils, are much more susceptible to invasion compared to grasslands of the Mixed Grass and Dry Mixed Grass Natural Subregions, which are underlain by brown soils. Three invasive agronomic grasses - Kentucky bluegrass, awnless brome and timothy - overall occur at a higher frequency in inventory plots than crested wheat grass or most noxious and nuisance weeds. Canada thistle, a noxious weed, is prevalent in plots of the Foothills Fescue and Foothills Parkland Natural Subregions, and in riparian areas throughout southern Alberta.

- Understories of deciduous forests and shrublands in the Grassland and Parkland Natural Regions of southern Alberta also become dominated by non-native species. This is documented in a recent report on vegetation classification in riparian areas of southern Alberta (Thompson and Hansen, 2002). Non-native species recorded as having $50 \%$ or greater cover in vegetation plots include awnless brome, Kentucky bluegrass, red top, sheep fescue, timothy and perennial sow-thistle. Barry Adams stated that an analysis of the number of riparian vegetation plots with non-native species could be provided if needed.

- An analysis of frequency of agronomic grasses and noxious and nuisance weeds in range plots within the Montane and Subalpine Natural Regions in southwest Alberta can be provided if needed. Mike Alexander highlighted some site-specific examples of non-native species invasion in the southwest. One example is that only $10 \%$ foothills rough fescue cover remains today inside an ungrazed range exclosure ( $65 \mathrm{~m} \times 40 \mathrm{~m})$ following contamination by brome hay 15 years ago. One foothills rough fescue grassland range exclosure in the Castle drainage which had little non-native species cover in 1953 was co-dominated by agronomic grasses by the mid-1970s. Relative foothills rough fescue cover increased during drought years of the mid 1980s but lost competitive advantage to Kentucky bluegrass and timothy in the wet years that followed. 
Table 1: Percent frequency ${ }^{1}$ of invasive agronomic grasses in range plots by natural subregion and within riparian plots in southern Alberta.

\begin{tabular}{|l|c|c|c|c|}
\hline $\begin{array}{l}\text { Natural Subregion } \\
\mathrm{n}=\text { sample plots }\end{array}$ & Timothy & Awnless brome & $\begin{array}{c}\text { Kentucky } \\
\text { bluegrass }\end{array}$ & $\begin{array}{c}\text { Crested } \\
\text { Wheatgrass }\end{array}$ \\
\hline $\begin{array}{l}\text { Dry Mixed Grass } \\
\mathrm{n}=1628\end{array}$ & 0 & $\mathrm{~T}$ & 5 & 2 \\
\hline $\begin{array}{l}\text { Mixed Grass } \\
\mathrm{n}=724\end{array}$ & 2 & 6 & 32 & 4 \\
\hline $\begin{array}{l}\text { Foothills Fescue } \\
\mathrm{n}=283\end{array}$ & 36 & 7 & 68 & $\mathrm{~T}$ \\
\hline $\begin{array}{l}\text { Foothills Parkland } \\
\mathrm{n}=410\end{array}$ & 73 & 21 & 75 & $\mathrm{~T}$ \\
\hline $\begin{array}{l}\text { Riparian Research Plots } \\
\mathrm{N}=488\end{array}$ & 15 & 25 & 36 & 0 \\
\hline $\begin{array}{l}\text { Riparian Inventory Plots } \\
\mathrm{n}=872\end{array}$ & 47 & 78 & 87 & 17 \\
\hline
\end{tabular}

${ }^{1}$ Frequency means species are present in plots but does not imply infestation levels of the species in the transect

${ }^{2}$ Native Prairie Data Base, Public Lands Division, Alberta Sustainable Resource Development, Lethbridge

${ }^{3}$ Data from Riparian Research Plots for the grassland natural region, Cows and Fish Program

${ }^{4}$ Data from Riparian Health Assessment data base for the grassland and boreal natural regions, Cows and Fish Program

Table 2. Percent frequency ${ }^{1}$ of noxious and nuisance weeds within range plots by natural subregion and within riparian plots in southern Alberta.

\begin{tabular}{|l|c|c|c|c|c|}
\hline $\begin{array}{l}\text { Natural Subregion } \\
\mathrm{n}=\text { sample plots }^{2}\end{array}$ & $\begin{array}{c}\text { Canada } \\
\text { Thistle }\end{array}$ & $\begin{array}{c}\text { Tall } \\
\text { Buttercup }\end{array}$ & $\begin{array}{c}\text { Hound's } \\
\text { Tongue }\end{array}$ & Toadflax & $\begin{array}{c}\text { Perennial } \\
\text { Sow Thistle }\end{array}$ \\
\hline $\begin{array}{l}\text { Dry Mixed Grass } \\
\mathrm{n}=1628\end{array}$ & 1 & 0 & 0 & 0 & 0 \\
\hline $\begin{array}{l}\text { Mixed Grass } \\
\mathrm{n}=724\end{array}$ & 5 & 0.3 & 0.3 & 0.1 & 0 \\
\hline $\begin{array}{l}\text { Foothills Fescue } \\
\mathrm{n}=283\end{array}$ & 17 & 1 & $\mathrm{~T}$ & $\mathrm{~T}$ & 2 \\
\hline $\begin{array}{l}\text { Foothills Parkland } \\
\mathrm{n}=410\end{array}$ & 17 & 1 & 0 & 0 & 1 \\
\hline $\begin{array}{l}\text { Riparian Research Plots } \\
\mathrm{n}=488\end{array}$ & 22 & $\mathrm{~T}$ & $\mathrm{~T}$ & 0.4 & 12 \\
\hline $\begin{array}{l}\text { Riparian Inventory Plots } \\
\mathrm{n}=872\end{array}$ & 97 & 10 & 16 & 5 & $74^{5}$ \\
\hline
\end{tabular}

${ }^{1}$ Frequency means species are present in plots but does not imply infestation levels of the species in the transect

${ }^{2}$ Native Prairie Data Base, Public Lands Division, Alberta Sustainable Resource Development, Lethbridge

${ }^{3}$ Data from Riparian Research Plots for the grassland natural region, Cows and Fish Program

${ }^{4}$ Data from Riparian Health Assessment data base for the grassland and boreal natural regions, Cows and Fish Program

${ }^{5}$ Frequency for Sonchus spp., some which are native

- Understories of deciduous forests and shrublands in the Grassland and Parkland Natural Regions of southern Alberta also become dominated by non-native species. This is documented in a recent report on vegetation classification in riparian areas of southern Alberta (Thompson and Hansen, 2002). Non-native species recorded as having $50 \%$ or greater cover in vegetation plots include awnless brome, Kentucky bluegrass, red top, sheep fescue, timothy and perennial sow-thistle. Barry Adams stated that an analysis of the number of riparian vegetation plots with non-native species could be provided if needed. 
- In the northern parts of the Special Areas smooth brome has invaded many sites of native vegetation according to Lorne Cole. As these sites age the brome tends to lose vigor, productivity and competitive advantage and there is some invasion by native shrubby species.

\subsection{Rates of Invasion of Non-native Species}

- Non-native plant species invasion into native rough fescue grasslands of the Pekisko drainage has occurred within a corridor averaging about 50 metres wide along a road constructed to access a gas well in 1980 (Bradley et al., 2002). Crested wheat grass had $>10 \%$ cover in vegetation along eight transects extending to a distance of 7 to 26 metres from the unreclaimed road centre. Patches were observed as far as 40 metres from the road.

- Relevant studies in Glacier National Park, Montana regarding invasion by non-native species into foothills rough fescue grassland were referenced by Cheryl Bradley. In one study researchers found alien species invasion of ungrazed foothills rough fescue grasslands occurred up to 100 metres from both paved twoland roads and unimproved dirt roads, with further invasion anticipated over time (Tyser and Worley, 1992). Phleum pretense and Poa pratensis were particularly common among 15 alien species. Alien species richness declined away from roads. In another study, Tyser concluded that once established along roadways spotted knapweed is capable of expanding into adjacent foothills rough fescue grassland (Tyser and Key, 1998). Invasion is by a gradual, broad, frontal expansion characterized by increased stem density on the border of the knapweed colony and seedfall within 1 metre of the parent plant. Native plant community composition is altered.

- Data on invasion of awnless brome into native vegetation from patches in Saskathchewan's Wanuskewin Heritage Park were provided by Darcy Henderson. Rates of spread of brome patches mapped in 1990 and sampled again in 2002 by Dave Sharman are $0.18 \mathrm{~m} / \mathrm{yr}$ on uplands, $0.12 \mathrm{~m} / \mathrm{yr}$ on the north valley slope, $0.28 \mathrm{~m} / \mathrm{yr}$ on the south valley slope and $0.40 \mathrm{~m} / \mathrm{yr}$ in the valley bottom. The soil of the valley bottom site is a regosol whereas the soil of the valley slopes and upland is a chernozem.

- Experience and studies show that crested wheat grass is adapted to a wide range of habitats. It invades native grasslands and in so doing reduces native grass cover and plant species diversity. According to unpublished research results by Darcy Henderson crested wheat grass has persisted for 25 years on sites where it was seeded along an old pipeline right of way in northern mixedgrass prairie of central Alberta and Saskatchewan. Crested wheat grass is better adapted to persist on sloping sites with chernozem or regosol soils compared to flat or depressional sites with solonetz or gelysol soils. At ten sites sampled along the upwind edge (SW) of a WNW trending right of way, crested wheat grass has invaded an average of 1 to 4 metres into native mixedgrass prairie. Downwind the rates of encroachment may be $>2$ times greater. Lower rates of invasion are associated with moderate to high intensity grazing probably because the seed source is reduced.

- A 1984 report which recorded invasion of non-native species into lodgepole pine and spruce forest understories from seismic lines in the Rocky Mountain House area (Revel et al., 1984) was referenced by Arin MacFarlane. Seeded agronomics were common on seismic lines and persisted 10 to 30 years after seismic activity. Sweet clover and dandelion had spread up to $5 \mathrm{~m}$ into the forest edge. Creeping red fescue and timothy were recorded on the edge of lines aged 5-10 years however were not found on lines older than 10 years. All other species were confined to the line.

- As part of her MSc research, Arin MacFarlane is documenting rates of spread from seismic lines in aspen forest in the southern Boreal Forest. Seismic lines may be both a source (i.e. when non-native species have been seeded as part of reclamation) and a vector for spread of non-native species. Many seismic lines in her study area are re-cleared and about $40 \%$ experience vehicle use. Preliminary results indicate that after 20 years $65 \%$ of seismic lines have a non-native species in the adjacent forest. Dandelion was the most 
commonly found in the adjacent forest followed by timothy, Canada thistle and quack grass. Presently this does not result in conversion to an understory dominated by non-native species, probably because most non-native species growing on seismic lines are shade intolerant and are out-competed by native plant species, such as northern reed grass/bluejoint.

\subsection{Restoration Potential}

- Historical observations by range managers are that restoration of disturbances to native vegetation is more likely to occur naturally in areas of brown soil, occupied by mixedgrass and dry mixedgrass vegetation types, than in areas of black soil occupied by rough fescue or riparian vegetation types.

- A study in the Rumsey Block of central Alberta where an inventory of six gas well sites abandoned 5 to 13 years previously found fair to poor establishment of native species and invasion of non-native species used in reclamation into native fescue and mixedgrass prairie (Integrated Environments Ltd., 1991).

- The site of a well drilled in 1980 in native foothills rough fescue grassland in the Pekisko drainage supports a plant community whose herbaceous canopy cover still is dominated by two non-native grass species awnless brome and Kentucky bluegrass - and prairie rose has established as a shrub layer (Bradley et al., 2002).

- Lorne Cole noted there are examples of fields in east-central Alberta cultivated in the early 1900 s which have almost reverted to native mixedgrass vegetation after several decades of abandonment. There also are examples of abandoned cultivated fields that remain in an altered, low productivity condition. The stage of recovery depends on many factors including soil (sandy sites recover more quickly than clay), number of years cultivated, date of abandonment (1920's to 1940's), degree of soil erosion prior to or just after abandonment and grazing management. The disturbance history of many of these sites is not available which limits the ability to make specific conclusions about rates of recovery.

- Lorne Cole provided unpublished data from surveys of fields in the Special Areas which had been cultivated and planted to non-native Russian wild rye and crested wheat grass. One field was cultivated in the early 1900's, abandoned in the 1930's, re-broken in the late 1960's, seeded to Russian wild rye in 1971 or 1972, and grazed moderately in late fall ever since. Sampled in 1999 it consisted of $14 \%$ Russian wild rye, $41 \%$ native decreaser grasses, $17 \%$ native increaser grasses and $28 \%$ increaser forbs. Fields with a similar history but subjected to regular early season grazing consisted of stunted Russian wild rye, pasture sage and bare ground. Some re-establishment of native species, including needle-and-thread, western and northern wheat grass, and plains rough fescue, has been noted in old fields seeded to crested wheat grass.

- Studies and personal observations of participants suggest the potential for recovery of foothills rough fescue grasslands to a native community is quite limited once invaded by non-native species. Reference was made to a study by Willoughby (1996) who found that some rangeland reference area sites which were fenced from grazing before Kentucky bluegrass became established, recovered to grassland dominated by foothills rough fescue, Idaho fescue and Parry oatgrass in 20-30 years. In contrast sites that had significant Kentucky bluegrass invasion prior to being fenced from grazing recovered to a grassland co-dominated by foothills rough fescue and Kentucky bluegrass.

- Barry Adams noted that attempts to reduce the cover and competitiveness of agronomic grasses in foothills rough fescue grasslands using fire, mowing and glyphosate have met with poor results (Brown, 1977; Willms, pers. comm.).

- Recent efforts to require minimum disturbance by industry and to restore disturbed sites to native condition are promising but have met with mixed results so far according to Marilyn Neville. Attempts at restoration of mixedgrass prairie have been more successful than restoration of rough fescue prairie. Preventing 
agronomic grasses from establishing on disturbed black soils and from invading adjacent rough fescue grasslands is particularly challenging. Generally, there is a lack of commitment to monitor the outcomes of reclamation of industrial disturbances so documentation of results of reclamation efforts is not available. Monitoring of reclamation results is underway in EnCana's gas field development south of the Cypress Hills in Alberta and Saskatchewan. As well, National Energy Board requires Express Pipeline to provide a report of results of a five-year monitoring program of reclamation of both plains rough fescue and mixedgrass prairie disturbed by construction of the pipeline in southeastern Alberta in the mid 1990s. The report is expected to be publicly available shortly. Monitoring of reclamation results on the Kerfoot property in the Wildcat Hills, which is under conservation easement to Nature Conservancy Canada, also is recommended.

\subsection{MODELING CONSIDERATIONS}

In considering the approach to modeling invasion by non-native plant species into native vegetation the discussion focused on four questions:

- Which invasive non-native species or species groups should we attempt to model?

- Should ALCES model a corridor of invasion or a rate of invasion from a footprint?

- How does invasion vary with land use footprints or footprint groups?

- How do reclamation techniques affect invasion characteristics?

\subsection{Invasive Non-Native Species Groups}

Participants recognize three groups of invasive non-native plant species in southern Alberta.

Group 1: Invasive Agronomics

These non-native species are introduced for agricultural or reclamation purposes. They readily spread, invade native rangelands and are known to persist. They are not considered noxious weeds in provincial and municipal laws and hence are not subject to control measures. Species included in this group are awnless brome, crested wheatgrass, Kentucky bluegrass, quack grass, red fescue, sheep fescue, sweet clover and timothy.

Group 2: Invasive Noxious Weeds

These non-native species are easily dispersed and readily colonize disturbed sites. They have the capability to move from disturbances into good condition rangelands and are known to persist. They are designated as noxious weeds in most provincial and municipal laws and are subject to control measures. Species included in this group are Canada thistle, houndstongue, leafy spurge, oxeye daisy, scentless chamomile, tall buttercup, field scabious/blue buttons, field toadflax and perennial sow thistle.

\section{Group 3: Poor Site Specialists}

These non-native species are easily dispersed and are adapted to establish and persist on bare impoverished soils. They do not invade productive rangelands in good condition. They are designated as noxious weeds in most provincial and municipal laws and are subject to control measures. Species included in this group are blueweed, dalmation toadflax, downy brome, knapweed and tansy.

Participants agreed that Invasive Agronomics are the most suitable group to be considered for modeling invasion of non-native species into native vegetation in southern Alberta. This is because these species are much more common and widespread than those in the other two groups and measures generally are not taken to control them. In addition there is sound information on the spread of Invasive Agronomics into native vegetation and on their subsequent dominance and persistence, whereas there is little information available for Invasive Noxious Weeds and Poor Site Specialists. 
Based on a review of available information and their observations participants decided that invasion of invasive agronomics into native vegetation is more appropriately modeled as a rate of invasion (meters/year) from a disturbance edge rather than as a corridor of set width. A corridor approach would imply that invasion stops at a set distance from a disturbance. Although there is evidence to suggest that the invasion rate may decrease over time, invasion is expected to continue indefinitely as long as invasive agronomics have competitive advantage over native species.

\subsection{Land Use Footprint Groups}

Participants recognize two main groups of land use footprint types defined in ALCES relative to non-native species invasion - Linear Footprints and Non-Linear Footprints. Participants decided to consider invasion of non-native species only from linear land use footprints because of the following considerations.

- Most of the available information documenting invasion of non-native species into native vegetation relates to linear disturbances such as roads, pipelines and seismic lines. There is much less known about the character of non-native species invasion from non-linear disturbances such as well sites, rural residential lots, recreational facilities, mine sites or industrial facilities.

- The date and extent of linear disturbances generally is recorded and transects perpendicular to the linear disturbance are easily used to monitor rates of invasion. For non-linear disturbances, often the date of origin and exact extent of the original footprint is not known. In addition, monitoring growth of non-native species patches or polygons over time is more challenging to researchers than measuring spread along transects.

- Linear land use footprints serve as sources and vectors for non-native species invasion across large areas of the landscape, including large blocks of native vegetation. The areal extent of non-native species invasion from non-linear land use footprints probably is small compared to that of linear disturbances.

\subsection{Reclamation Considerations}

Participants recognize three periods in reclamation practices with respect to invasive agronomic species which need to be considered when modeling their invasion into native vegetation from land use footprints which are being reclaimed.

Pre-1975: Invasive agronomics, and in particular crested wheatgrass, were generally not seeded during reclamation hence disturbed sites were available for recolonization by native plant species. It is assumed that, with some exceptions, there was not significant invasion by invasive agronomics, from land use footprints which were constructed and abandoned during this period.

1975-1995: Native vegetation and top soil were removed and agronomic species such as crested wheat grass, awnless brome, timothy, Kentucky blue grass and clover were seeded during reclamation. Invasive agronomics had a competitive advantage over native plants and invaded native vegetation. It is assumed that rates of invasion by invasive agronomics into adjacent native vegetation will be highest for land use footprints created during this period.

1995-present: Minimum disturbance techniques are used and reclamation practices in southern Alberta generally, but not always, include use of native seed mixes instead of invasive agronomics. Compared to the pre-1970 period, there are more sources of non-native species propagules, including those of 
invasive agronomics, which are brought in by wind, animals, humans and vehicles. It is assumed that there will be invasion of invasive agronomics from land use footprints during this period but overall at lower rates than for the 1970-1995 period.

\subsection{ESTIMATED INVASION RATES}

Based on the review of background information and their own observations, participants estimated rates of invasion for a group of widespread agronomic species known to invade native vegetation (Table 3). Rates were defined for each native landscape cover type in ALCES and for each linear footprint type. For linear disturbances which are routinely reclaimed (i.e. pipelines and seismic lines), two periods of restoration with differing rates of invasion were considered. Assumptions articulated by participants in making the estimations follow.

\subsection{Assumptions}

We have reached our conclusions based on the background information and expert knowledge available to us as this time. There are however significant gaps in our understanding of the 'shadow effects' from land use footprints. We assume that the conclusions we reach today will be a useful starting point for understanding the effects of non-native species invasion on native vegetation, but that others will refine the approach as more information becomes available.

A conservative approach enhances the credibility of the model, hence our estimates of rates of invasion err on the low side.

Our estimated rates of invasion refer to rates of conversion of native vegetation types to non-native types which we define as vegetation types in which non-native plant species dominate canopy cover. Spread of non-native plant species into native vegetation through establishment of isolated individuals or patches will occur at higher rates.

In some areas of southern Alberta substantial invasion of non-native species into native vegetation occurred throughout the early 1900 s, some of this attributable to livestock use and some to broadcasting of seed into native range by humans. These land use activities do not correlate with a land use footprint defined in ALCES. We assume that this 'background' invasion will be captured in range health assessment information being provided to ALCES.

Rates of invasion apply to permanent linear footprints (roads, canals) from the time they were created. However, we have assumed that vegetated linear footprints (i.e. seismic lines and pipelines) created prior to 1975 reverted to native condition. Prior to 1975, invasive agronomics were not used in reclamation and they were not as widespread hence less likely to invade disturbed sites. This is a conservative assumption as revegetation to native has likely not occurred in all pre-1975 situations

Our estimated rates of invasion increase with fertility of parent material and water enrichment. Hence, for example, rates estimated for fescue grassland, which occurs in areas of greater annual precipitation, are higher than rates estimated for mixed grassland. Estimated rates within riparian cottonwood complexes are the highest given that these sites are especially well watered and fertile. Within each of the native vegetation cover types identified in ALCES, there also will be a variation in fertility of parent material and water enrichment. For example awnless brome can be expected to invade swales and not hilltops in mixed grasslands. We have attempted to estimate an average rate of invasion given the variation within each of these cover types.

ALCES models two generations or approximately 50 years hence that is the time frame we are considering with respect to invasion and restoration. Since there is not information to the contrary, we are assuming that 
invasion from various land use footprints will continue throughout the time frame modeled by ALCES and that once a vegetation type is dominated by non-native species, restoration to native condition will not occur. It has been suggested that

Overlapping disturbances will affect rates of invasion by non-native species. For example, severe livestock grazing increases rate of invasion for some species, such as awnless brome, Kentucky bluegrass and timothy, but reduces rate of invasion for crested wheat grass. We assume all land use footprints supporting vegetation will be moderately grazed by livestock and wildlife following disturbance and that moderate grazing will have a neutral effect on rates of invasion. We also assume that most seismic lines and transmission lines in forested areas and all bladed trails throughout the study area will be used by vehicles following their initial construction. This vehicle use will provide a vector for further introduction and dispersal of non-native plants species. Roads and canals are assumed to be permanent disturbances which are a continuing source area for non-native species invasion and with no reasonable prospect for restoration to native vegetation. 
APPENDIX A

WORKSHOP AGENDA 


\section{Workshop on Invasive Plants}

9:00 a.m. - 4:30 p.m., Monday, 14 April 2003

Room 131, AAFRD Boardroom, Agricultural Centre, Lethbridge

\section{$\underline{\text { Agenda }}$}

Welcome and Introductions (9:00 a.m.)

- experience regarding invasive plants

Purpose of Workshop

- SAL and ALCES Background

- Reasons for modeling invasion of non-native species into native vegetation

- Key challenges/constraints/pitfalls

Information Base

- Existing information sources

- Gaps in information

Break (10:30 a.m.)

Elements to be Modeled in ALCES

- Invaders: single species or grouping(s)?

- Native vegetation types in ALCES: all, some, groupings?

- Disturbances in ALCES: all or groupings based on type, date, reclamation history?

Lunch (11:45 a.m.-12:30 p.m.)

Modeling Invasion in ALCES

- Buffer or rate?

- Period(s) for restoration

- Thresholds re fragmentation

- Define for each disturbance and vegetation element

Break (2:45 p.m.)

Assumptions and Differences of Opinion (if any)

Next Steps

Adjourn (4:30 p.m.) 
APPENDIX B

PARTICIPANTS LIST 


\section{Barry Adams}

Public Lands, Alberta Sustainable Resource Development

Address: Agriculture Centre, 100, 5401 - 1 Ave. S., Bag 3014, Lethbridge AB T1J 4C7

Phone: (403)382-4299

Fax: (403)381-5792

E-mail: barry.adams@gov.ab.ca

\section{Mike Alexander}

Public Lands, Alberta Sustainable Resource Development

Address: P.O. Box 540, Blairmore AB TOK 0E0

Phone: (403)562-3141

Fax: (403)562-7143

E-mail: mike.alexander@gov.ab.ca

\section{Lorna Allen}

Alberta Natural Heritage Information Centre, Alberta Community Development Address: 2nd Flr Oxbridge, 9820 - 106 St., Edmonton AB T5K 2 J6

Phone: (780) 427-6621

Fax: (780) 427-5980

E-mail: 1orna.allen@gov.ab.ca

\section{Cheryl Bradley}

Consultant

625 - 18 St. S., Lethbridge AB T1J 3E9

Phone: (403)328-1245

Fax: (403)380-4969

E-mail: cebradley@shaw.ca

\section{Lorne Cole}

Special Areas Board, Alberta Municipal Affairs

Address: P.O. Box 820, Hanna AB T0J 1P0

Phone: (403)854-0293

Fax: (403)854-5527

E-mail: lorne.cole@gov.ab.ca

\section{Darcy Henderson}

Department of Renewable Resources, University of Alberta

Address: 751 General Services Building, U of A, Edmonton, Alberta T6G 2H1

Phone: (780)454-0809

Fax: (780)492-4323

E-mail: darcyh@ualberta.ca 
Arin MacFarlane

Department of Biological Sciences, University of Alberta

Address: CW 312 Biological Sciences Bldg, U of A, Edmonton AB T6G 2E9

Phone: (780)675-3106

(780)492-2539

Email: arin@ualberta.ca

\section{Marilyn Neville}

Gramineae Consultants

Address: Box 95, Lundbreck AB TOK $1 \mathrm{HO}$

Phone: (403) 628-2875

Fax: (403)628-2493

E-mail: graminea@telusplanet.net

\section{Brad Stelfox}

Forem Technologies

Address: Box 805 Bragg Creek AB TOK OK0

Phone: (403)949-3008

Fax: (403)949-2663

E-mail: bstelfox@telusplanet.net 
APPENDIX C

\section{LIST OF REFERENCES}


Adams B.W., R. Ehlert, D. Moisey and R. McNeil. 2003. Rangeland Plant Communities and Range Health Assessment Guidelines for the Foothills Fescue Grassland of Alberta. Rangeland Management Branch, Public Lands Division, Alberta Sustainable Resource Development Lethbridge, Pub. No. T/038.

Ambrose L.G. and S.D. Wilson. 2003. Emergence of the introduced grass Agropyron cristatum and the native grass Bouteloua gracilis in a mixed-grass prairie restoration. Restoration Ecology 11:110-115.

Axys Environmental Consulting Ltd. 2001. Express Pipeline Ltd. Environmental Monitoring Report. Prepared for Express Pipeline Ltd. Calgary, AB.

Bradley, C., M. Quinn and D. Duke. 2002. Local and Regional Ecological Effects Analysis: Proposed Drilling Program of Vermillion Resources Ltd. in an area of Native Foothills Parkland (Well Licence Application No. 1247320). Pekisko Land Owners Association.

- Vegetation on a well site in foothills fescue grassland reclaimed in 1980 was dominated by wild rose (34\% cover), smooth brome (46\%) and Kentucky bluegrass (33\%). Along the access road, non-native plant species invasion occurred within a corridor averaging 50 to 70 metres wide. Crested wheat grass was a dominant species up to 26 metres from the road and patches had invaded 40 metres from the road.

Broersma K. M. Krzic, D.J. Thompson and A.A. Bomke. 2000. Soil and vegetation of ungrazed crested wheatgrass and native rangelands. Canadian Journal of Soil Science 80:411-417.

Brothers T.S. and A. Springarn. 1992. Forest fragmentation and alien plant invasion of central Indiana oldgrowth forests. Conservation Biology 6:91-100.

- Rates of spread of dandelion and other species in forest fragments bordering agriculture. Interestingly, the most successful invaders were commonly escaped ornamentals not agricultural weeds.

Brown D. 1997. Smooth brome (Bromus inermis) in foothills fescue grassland: stand characterization and the effects of cattle, sheep, mowing, glyphosate and fire. MSc Thesis, University of Alberta, Edmonton AB. 136 pp.

Cameron, D.S., D.J. Leopold, and D.J. Raynal. 1997. Effect of landscape position on plant diversity and richness on electric transmission rights-of-way in New York State. Canadian Journal of Botany 75 : 242-251.

- Weeds were common on corridor but there were few occurrences in surrounding forest however non-natives were mostly absent from wetland areas.

Christian J.M. and S.D. Wilson. 1999. Long-term ecosystem impacts of an introduced grass in the northern Great Plains. Ecology 80:2397-2407.

Christiansen, P. 1990. Alien species cover on the perimeter of two northwest Iowa prairies. In Smith, D and C. Jacobs, ed. Proceedings of the twelfth North American Prairie Conference 1990. University of Northern Iowa, Cedar Falls.

- Alien species occurred a mean distance of $22.8 \mathrm{~m}$ (range $16.2 \mathrm{~m}-28.0 \mathrm{~m}$ ) in from the edge of a native prairie. Prairie less than 0.2 ha would not be expected to have any areas free of alien species.

Clark G.T. 1998. Fescue grassland restoration: integrating research and experience into a fescue grassland conservation strategy. pp 61-65 In. Proceedings of the Fifth Prairie Conservation and Endangered Species Conference. Saskatoon, Saskatchewan. Provincial Museum of Alberta Natural History Occasional Paper No. 24.

- Native seed mixes established better in the dark brown soil zone and on knolls compared to the black soil zone (fescue grassland and parkland) and foot-slopes. Native plantings in the black soil 
zone were more seriously invaded by perennial weeds and experienced poorer seed production than native plantings in the mixed and tall-grass prairie region. These problems generally become more severe as one moves west in the parklands. Recommends conserving fescue prairie rather than attempting to restore it.

D'Antonio C.M. and P.M. Vitousek. 1992. Biological invasions by exotic grasses, the grass/fire cycle, and global change. Annual Review of Ecology and Systematics 23:63-87.

Dormaar J.F., M.A. Naeth, W.D. Willms and D.S. Chanasyk. 1995. Effect of native prairie, crested wheatgrass (Agropyron cristatum (L.) Gaertn.) and Russiand wild rye (ELymus junceus Fisch.) on soil chemical properties. Journal of Range Management 48:258-263.

Gelbard J.L. 2003. Roads as conduits for exotic plant invasions in a semiarid landscape. Conservation Biology $17(2): 420-432$.

Greenberg, C., S. Crownover, D. Gordon. 1997. Roadside soils: a corridor for invasion of xeric scrub by nonindigenous plants. Natural Areas Journal Vol. 17 (2), 1997: 99-109.

- Roadways facilitate the spread of nonindigenous plant species to remote sites. Ecosystems adjacent to roads constructed using modified soils (clay, limerock) are more susceptible to invasion by nonindigenous species than roads constructed using native soils (sand).

Grilz, P. and J. Romo. 1995. Management considerations for controlling smooth brome in fescue prairie. Natural Areas Journal Vol. 15(2), 1995: 148-156.

- Smooth brome is an aggressive invader of plains rough fescue grasslands. Control of smooth brome can be achieved with spring burning followed by wick application of glyphosate; however, native species are reduced. Regular monitoring and control of smooth brome invasions is needed to prevent its spread in rough fescue grassland.

Hayden Reichard, S. and P. White. 2001. Horticulture as a pathway of invasive plant introductions in the United States. BioScience February 2001 Vol. 51 No. 2; 103 - 113

- Defines an invasive plant species as one that spreads into native flora, develops self-sustaining populations, and become dominant or disruptive (or both) to those systems. Notes that invasion may be related to available resources in the native plant community which often correlates with species richness. "Invasions are capricious and cannot be anticipated or screened".

Harper, K., R. Van Buren, S. Kitchen. 1996. Invasion of alien annuals and ecological consequences in salt desert shrublands of western Utah. Pgs 58 - 65 in Barrow, J., E. McArthuer, R. Sosebee, R. Tasch, eds. 1996 Proceedings: shrubland ecosystems dynamics in a changing environment; 1995 May 23-25; Las Cruces, NM. Gen. Tech. Rep. INT-GTR-388. Ogden UT: USDA, Forest Service, Intermountain Research Station.

- In vegetation plots in shadscale-winterfat communities mapped periodically since 1937 Bromus tectorum was first observed in 1958. It had become common on both grazed and ungrazed plots by 1989 , although plant density and vigor was reduced on ungrazed sites.

Heidinga L. and S.D. Wilson. 2002. The impact of an invading alien grass (Agropyron cristatum) on species turnover in native prairie. Diversity and Distributions 8:249-258.

Hobbs, R.J. and L.F. Huenneke. 1992. Disturbance, diversity, and invasion: implications for conservation. Conservation Biology 6: 324-337.

- Review of invasions globally and also a review of the factors influencing establishment and spread as well as control of invasions (fire, grazing, soil disturbance, fragmentation etc.) 
Holcroft Weerstra, A.C., Biota Consultants. 2003. Plains Rough Fescue (Festuca hallii) Grassland Mapping Central Parkland Natural Subregion of Alberta. A report Prepared for Resource Data Branch, Alberta Sustainable Resource Development, Edmonton, Alberta.

- The project involved mapping native prairie remnants in the central parkland, than field checking those with significant grassland components that had some chance of being fescue grasslands, so only upland grassland sites are part of the 1,686 total sites checked. Plains rough fescue communities were recorded in only 211 (12.5\%) of the 1,686 recorded sites. However, plains rough fescue plants were found at an additional 338 sites, or $32.7 \%$ of all 1,686 records. Sixty-five of the plains rough fescue communities were estimated to be in good or excellent condition (invasive non-native plants were observed in $23(35.4 \%)$ ); 98 were estimated to be in fair or fair to good condition (invasive non-native plants observed in $35(35.7 \%)$ ); and, 62 were estimated to be in fair to poor or poor condition (invasive non-native plants observed in $36(58.1 \%)$ ). This adds up to 225 sites, not 211 because some records list more than one Festuca hallii community. In total, invasive non-native plants were found in $41.8 \%$ of the plains rough fescue communities.

Integrated Environments Ltd. 1991. Vegetation Inventory of Various Industrial Sites in the Rumsey Block. Prepared for Public Lands Division, Alberta Forestry, Lands and Wildlife.

- Vegetation inventories of six gas well sites abandoned 5 to 13 years previously found fair to poor establishment of native species and invasion into native grasslands of non-native species used in reclamation (awnless brome, yellow sweet clover). Revegetation by native species of two pipeline right-of-ways was more promising. Rough fescue in reclamation seed mixes had not become established. Cattle concentrated on the disturbed sites suggesting cattle management should be a key aspect of revegetation programs.

Kerr D.S., L.I. Morrison and K.E. Wilkinson. 1993. Reclamation of native grasslands in Alberta: a review of the literature. Alberta Land Conservation and Reclamation Council Report No. 9101. 205 pp plus appendices

Kotanen P.M., J. Bergelson and D.L. Hazlett. 1998. Habitats of native and exotic plants in Colorado shortgrass steppe: a comparative approach. Canadian Journal of Botany 76:664-672.

Krzic M., K. Broersma, D.J. Thompson and A.A. Bomke. 2000. Soil properties and species diversity of grazed crested wheatgrass and native rangelands. Journal of Range Management 53:353-358.

Lesica P. and T.H. DeLuca. 1996. Long-term harmful effects of crested wheatgrass on Great Plains grassland ecosystems. Journal of Soil and Water Cosnervation 51:408-409.

Mack R.N. 1989. Temperate grasslands vulnerable to plant invasions: characteristics and consequences. Pages 155-179 in J.A. Drake, H.A. Mooney, F. di Castri et al. editors. Biological invasions. Wilery \& Sons, New York.

Mack R.N., D. Simberloff, W.M. Lonsdale, H. Evans, M. Clout and F.A. Bazzaz. 2000. Biotic invasions: causes, epidemiology, global consequences and control. Ecological Applications 10:689-710.

Marlette G.M. and J.E. Anderson. 1986. Seed banks and propagule dispersal in crested-wheatgrass stands. J. Appl. Ecol. 23:161-175.

McIntyre S and S. Lavorel. 1994. Predicting richness of native, rare, and exotic plants in response to habitat and disturbance variables across a variegated landscape. Conservation Biology 8 (2):521-31.

- Total exotic species in temperate grasslands in New South Wales increases with increasing natural fertility of parent material, water enrichment, severe livestock grazing and soil disturbance whereas native species richness declines. Presence of exotics alone may have a negative effect on natives through competitive interactions. 
McKinney M.L. 2002. Influence of settlement time, human population, park shape and age, visitation and roads on the number of alien plant species in protected areas in the USA. Divers. Distrib. 8:311-318.

Meekins, J.F. and B.C. McCarthy. 2001. Effect of environmental variation on the invasive success of a nonindigenous forest herb. Ecological Applications 11(5): 1336-1348.

Moody M.E. and R.N. Mack. 1988. Controlling the spread of plant invasions: The importance of nascent foci. J. Appl. Ecol. 25:1009-1021.

Myers, J.H. and D.E. Berube. 1983. Diffuse knapweed invasion into rangeland in the dry interior of British Columbia. Can. J. Plant Sci. 63:981-987.

- Diffuse knapweed, which disperses seeds in a tumble-weed manner, advanced into native grasslands at a rate of approximately $40 \mathrm{~m} /$ year.

Naeth, Anne. 1997. Environmental Restoration: Can We Reclaim What We Have Disturbed? Presentations to students and staff at the University of Alberta.

http://www.ualberta.ca/ERSC/98Seminars/news7.htm

http://www.ualberta.ca/ALUMNI/newtrail/97-3/banff.html

- Reclamation is returning disturbed land to productive use and equivalent land capability.

Restoration involves returning the conditions and ecosystem that existed in an area before it was disturbed by humans.

Native Plant Working Group. 2000. Native Plant Revegation Guidelines for Alberta. H. Sinton-Gerling (ed.). Alberta Agriculture, Food and Rural Development and Alberta Environment. Edmonton, Alberta. 58 pages.

Native Prairie Guidelines Working Group. 2002. Petroleum Industry Activity in Native Prairie and Parkland Areas: Guidelines for Minimizing Disturbance. Energy Utililities Board, Calgary. 36 pp. http://www.eub.gov.ab.ca/bbs/documents/reports/NativePrairieGuidelines.pdf

Parker I.M., D. Simberloff, W.M. Lonsdale, K. Goodell, M. Wonham, P.M. Kareiva, M.H. Williamson, B. Von Holle, J.E. Byers and L. Goldwasser. 1999. Impact: toward a framework for understanding the ecological effects of invaders. Biological Invasiona 1:3-19.

Parendes, L.A. and J.A. Jones. 2000. Role of light availability and dispersal in exotic plant invasion along roads and streams in the H.J. Andrews experimental forest, Oregon. Conservation Biology 14(1): 6475 .

Pimentel D., S. McNair, J. Janecka, J. Wightman, C. Simmonds, C. O’Connel, E. Wong, L. Russel, J. Zern, T. Aquino and T. Tsomondo. 2001. Economic and environmental threats of alien plant, animal, and microbe invasions. Agriculture, Ecosystems and Environments 84:1-20.

Public Lands Division. n.d. Native Prairie Data Base. Alberta Sustainable Resource Development. Lethbridge $\mathrm{AB}$.

Pyke D.A. 1990. Comparative demography of co-occurring introduced and native tussock grasses: persistence and potential expansion. Oecologia 82:537-543.

Pyske, P. and K. Prach. 1993. Plant invasions and the role of riparian habitats: a comparison of four species alien to central Europe. Journal of Biogeography, Vol. 20, pp. 413-420. 
Radosevich S.R., M.M. Stubbs and C.M. Ghersa. 2003. Plant invasions - process and patterns. Weed Sci. 51:254-259.

Revel, R.D., T.D. Dougherty, and D.J. Downing. 1984. Forest Growth and Revegetation Along Seismic Lines. University of Calgary Press, Calgary AB.

- Details on the revegetation of seismic lines of the Rocky Mountain House area. Includes descriptions of plant communities (many non-native species) on the line and off the line, however, does not use statistical analysis to describe general patterns. Found presence of seeded agronomics 10-30 yrs after seismic creation.

Sinton H.M. 2001. Prairie Oil and Gas: A Lighter Footprint. Alberta Environment. 67 pages.

Smith M.D. and A.K. Knapp. 2001. Physiological and morphological traits of exotic, invasive exotic and native plant species in tallgrass prairie. International Journal of Plant Science 162:785-792.

Sutter G.C. and R.M. Brigham. 1998. Avifaunal and habitat changes resulting from conversion of native prairie to crested wheatgrass: patterns at songbird community and species levels. Canadian Journal of Zoology 76:869-875.

Tannas, Kathy. 1998. Common Plants of the Western Rangelands (Volume I and II).Lethbridge Community College. 622 pp.

Thompson W.H. and P.L. Hansen. 2002. Classification and Management of Riparian and Wetland Sites of Alberta's Grassland Natural Region. Cows and Fish Report No. 018.

Tyser, R., C. Worley. 1992. Alien flora in grasslands adjacent to road and trail corridors in Glacier National Park, Montana. Conservation Biology Volume 6, No. 2, Pages 253-261.

- Alien species invasion of ungrazed rough fescue grasslands occurred up to 100 metres from both paved two-land roads and unimproved dirt roads, with further invasion anticipated over time. Phleum pretense and Poa pratensis were particularly common among 15 alien species. Alien species richness declined away from roads. Management recommendations are to avoid roadbuilding in bunch grass communities and to intensively monitor and manage alien flora where roads already exist.

Tyser, R., C. Key. 1998. Spotted knapweed in natural area fescue grasslands: an ecological assessment. Northwest Science, Vol. 62, No. 4, 1988: 151-160.

- Once established along roadways spotted knapweed is capable of expanding into adjacent fescue grassland. Invasion is by a gradual, broad, frontal expansion characterized by increased stem density on the border of the knapweed colony and seedfall within 1 metre of the parent plant. Native plant community composition is altered.

USDA. 1988. Range Plant Handbook. Reprint of original 1937 Handbook. Dover Publications, New York. 809 pp.

Weerstra, A.H. 2000. Control Options for Smooth Brome (Bromus inermis) in the Rumsey Ecological Reserve - A Review and Summary of Relevant Research and Experience of Practitioners. Public Lands Division.

- Vegetation types most prone to smooth brome invasion are boreal forest, aspen parkland and fescue prairie. The grasslands of the mixed prairie are more resistant to invasion, however moister sites with better soil (riparian zones) have been invaded. Smooth brome is considered the most invasive non-native species in Saskatchewan. It invades new habitat as an advancing front spread by rhizomes and seed and suppressing the growth of native species. Protection from livestock grazing does not necessarily preclude smooth brome invasion. 
Willoughby M.G. 1996. Rangeland Reference Areas: Castle River Range Condition and Trend from 19531995. Environmental Protection, Lands and Forest Services. Edmonton, AB. 10 pp.

Wilson S.D. and J.W. Belcher. 1989. Plant and bird communities of native prairie and introduced Eurasian vegetation in Manitoba, Canada. Conservation Biology 3:39-44.

With, K.A. 2002. The landscape ecology of invasive spread. Conservation Biology 16(5):1192-1203.

- Theoretical discussion of how landscape patterns affect the spread of invasive species 


LIBRARY AND ARCHIVES CANADA

Bibliothèque et Archives Canada

3 3286538600640 